\title{
The Effects of Terminalia catappa L. Leaves Extract on the Water Quality Properties, Survival and Blood Profile of Ornamental fish (Betta sp) Cultured
}

\author{
${ }^{\square}$ Rudy Agung Nugroho, Hetty Manurung, Dewi Saraswati, Deasy Ladyescha, Firman \\ Muhammad Nur
}

DOI: 10.15294/biosaintifika.v8i2.6519

Department of Biology, Faculty of Mathematics and Natural Sciences, Mulawarman University, Indonesia

\section{History Article \\ Received 1 July 2016 Approved 6 August 2016 Published 18 September 2016}

\section{Keywords:}

Terminalia catappa L.; Betta sp; phytochemical; Survival; haematological profile

\begin{abstract}
This research aimed to determine the phytochemicals content of Terminalia catappa leaves extract (TCL) and its effects on the survival and blood profiles of ornamental fish (Betta sp) Ninety fish were randomly assigned into six triplicates groups and reared in various concentration of TCL: 0 (control), 125, 250, 375, 500, $625 \mathrm{ppm}$ for 30 days. Temperature, Dissolve oxygen (DO), and $\mathrm{pH}$ were monitored during the trial. After 30 days, survival, Red Blood Cells (RBC), White Blood Cells (WBC), haemoglobin $(\mathrm{Hb})$, lymphocyte, and total protein serum (TPS) were analyzed. Based on the phytochemicals test, saponin, triterpenoid, quinon, phenolic, tannin, and flavonoid were detected on the TCL. Temperature and DO were not affected by any concentration of TCL. The lowest $\mathrm{pH}$ (5.05) was found in fish medium immersed with $625 \mathrm{ppm}$ of TCL. Adding TCL above $375 \mathrm{ppm}$ resulted in significantly higher survival, $\mathrm{RBC}$, and $\mathrm{Hb}$. The highest WBC was found in fish immersed with $625 \mathrm{ppm}$ whereas the lowest lymphocyte was found in fish immersed with 375 of TCL. However, immersing any various concentration of TCL did not affect on the TPS. In summary, immersing TCL above $375 \mathrm{ppm}$ is beneficial to enhance survival, $\mathrm{RBC}, \mathrm{WBC}$, and $\mathrm{Hb}$ of Betta sp.
\end{abstract}

\section{How to Cite}

Nugroho, R. A., Manurung, H., Saraswati, D., Ladyescha, D. \& Nur, F. M. (2016). The Effects of Terminalia catappa L. Leaves Extract on the Water Quality Properties, Survival and Blood Profile of Ornamental fish (Betta $s p$ ) Cultured. Biosaintifika: Journal of Biology \& Biology Education, 8(2), 240-247.

(C) 2016 Semarang State University $\bowtie$ Correspondence Author:

J1. Barong Tongkok No 4, Gn Kelua, Samarinda, East Kalimantan, Indonesia

E-mail: rudysatriana@yahoo.com
p-ISSN 2085-191X

e-ISSN 2338-7610 


\section{INTRODUCTION}

Terminalia species are widely distributed both in tropical and sub-tropical regions, including Asian (Hyttel et al., 2009; Hyttel et al., 2010). In Indonesia, Terminalia catappa L. is an attractive, long-lived tree well suited to ornamental and amenity plantings. The water extract of Terminalia catappa leaves (TCL) has also been known as a folk medicine for antipyretic, haemostatic, hepatitis and liver-related diseases purposes in Philippines, Malaysia and Indonesia (Meena \& Raja, 2006; Vučurović \& Razmovski, 2012).

Besides as the folk medicine, TCL has also been used in fish culture and breeder in various ways. Chitmanat et al. (2003) proved that TCL can be applied in Tilapia (Oreochromis niloticus) culture to protect the fish against the pathogen. The TCL sometimes referred as a miracle leaf by fish breeders across the globe, claiming its usefulness in creating spawns and citing wondrous healing properties. According to Pandey (2013), TCL has a potential as herbal biomedicine to improve non-specific defense mechanism of fish and elevate the specific immune response. The TCL is also said to be responsible for, lowering $\mathrm{pH}$, and treating water hardness $(\mathrm{kH})$. Although the claims are tremendous and vast, the TCL has little scientific research done on all of the claims of its beneficial properties, especially on hematological profile of fish.

The immune status of fish is related to haematology condition which is importance in fish culture because of its value in monitoring the health status of fish (Chandel et al., 2009). Haematological condition such as total erythrocyte count (RBC), white blood cells (WBC) count, haemoglobin count $(\mathrm{Hb})$ and total protein in the serum of fish is an effective tool that can be used to evaluate physiological and pathological changes in fish (Inama et al., 1993). Moreover, WBC has been regularly used as indicators of health status in fish because WBC is key components of innate immune defense and involved in regulation of immunological function in fish including ornamental fish (Betta sp) (Zhou et al., 2010; Ekman et al., 2013).

Ornamental fish, Betta $s p$, belongs to the Labyrinth fish family (Belonitiidae) and known as a colorful species, especially in males (Ekman et al., 2013). As an important cultured species in Indonesia, Betta $s p$ is recognized as a valuable fish commodity, increasing market demand for this fish has led to a significant boost in research to improve survival and health performance of the fish. However, the information regarding the ef- fects of TCL on the medium water quality, survival and blood profile of Betta sp is limited. Thus, the current study was designed to evaluate, water quality in the medium (Temperature, Dissolve oxygen, and $\mathrm{pH}$ ), survival rate, $\mathrm{RBC}, \mathrm{WBC}$, total $\mathrm{Hb}$, the percentage of lymphocyte, and total protein serum in the blood of Betta sp exposed to different concentration of TCL. Also, the phytochemical compounds in the extract which probably responsible for blood profiles properties were also identified.

The outcome of this research is beneficial to determine the benefit of the phytochemicals in TCL to improve the physiological condition of Betta sp. Further, the optimum concentration of TCL immersion which was obtained in this research can be used to enhance the health of Betta sp as indicated by survival and blood profile.

\section{METHODS}

\section{Plant Material}

Terminalia catappa's dried cut brown leaves were collected on the campus of Mulawarman University, Barong Tongkok, East Kalimantan, Indonesia. In purpose of eliminating the extraneous matter, thecollected T. catappa's leaves were washed with deionized water and immediately dried in an oven at $40^{\circ} \mathrm{C}$ for $12 \mathrm{~h}$. T. catappa's powder (8 opening $\mathrm{cm}^{-1}$ passed) was obtained using a mill. The powder was extracted with ethanol $95 \%$ for three days $\left(100 \mathrm{~g} \mathrm{~L}^{-1}\right)$. After filtration, the extract was evaporated by using rotary evaporator and stored at $4^{\circ} \mathrm{C}$ until used as a crude extract.

\section{Preliminary Phytochemical Tests}

The preliminary phytochemical tests such as alkaloid, saponin, steroid, triterpenoid, quinon, phenolic, tannin, and flavonoid were performed to detect the presence of possible phytochemicals in the extract of T. catappa leaves, they are: (1) Test for alkaloid-Dragendorff Test: $2 \mathrm{~mL}$ of the filtrate was added by $1 \mathrm{~mL}$ of Dragendorff reagent along the side of the test tube. Formation of orange or orange reddish brown precipitate indicates a positive test. (2) Test for saponin, 1 $\mathrm{mL}$ of extract $+5 \mathrm{~mL}$ distilled water was shaken vigorously, the appearance of stable froth (1-3 height) for 15 minutes indicates the presence of saponin. (3) Test for steroids and (4) triterpenoid (Liebermann-Burchard), $2 \mathrm{~mL}$ extract $+1 \mathrm{~mL}$ chloroform + few drops of acetic anhydride + conc. sulphuric acid added along the side of the test tube), the appearance of blue or green colour indicated the presence of steroids, and appearance of red, brown colour indicates the presence 
of triterpenoid. (5) Test for Quinon, $1 \mathrm{~mL}$ of extract $+1 \mathrm{~mL}$ of conc. sulfic acid. A red coloration indicated the presence of quinon. (6) Test for phenols and tannins: crude extract was mixed with $2 \mathrm{~mL}$ of $2 \%$ solution of $\mathrm{FeCl} 3$. A blue-green or black coloration indicated the presence of phenols and tannins. (7) Test for flavonoids $(2 \mathrm{~mL}$ extract + conc. hydrochloric acid + magnesium ribbon), the appearance of pink-red colour indicated the presence of flavonoids.

\section{Animals and Experimental Setup}

Ninety Siamese fighting fish (male with average initial weight $0.62 \mathrm{~g}$; Crown tail), 2-monthold, were purchased from Local breeding Farm, Samarinda East Kalimantan and acclimated at Animal Physiology, Development, and Molecular Laboratory, Mulawarman University, East Kalimantan for a week. Fish were then randomly distributed into six triplicate groups of five Siamese fighting fish each group. Each group of Siamese fighting fish was then placed in a glass tank $(0.5 \mathrm{~L}$ capacity, $0.4 \mathrm{~L}$ of fresh water in each tank. The study was conducted for 30 days, fish in each group of treatment was added with a various concentration of TCL viz 125, 250, 375, 500, 625 ppm as immersion. Temperature, $\mathrm{pH}$, and Dissolve Oxygen (DO) were measured every secondday using a routine thermometer, $\mathrm{pH}$ meter, and TOA-dkk pH HM-7, TOA instrument, Japan. The fish in each glass tank was fed with frozen bloodworm at a rate of $1 \%$ of body weight every day. Previous experiments determined this feeding rate. Uneaten food and faeces were siphoned out before renewing the water. The water volume was renewed every second day using each treatment concentration and maintained to $0.4 \mathrm{~L}$ of water in every glass tank.

\section{Sampling and Analytical Procedure}

The survival rate of fish in each group was recorded every 10 days. At the day 30, blood samples were taken by caudal venipuncture after anaesthetizing the fish with MS-222 $\left(200 \mathrm{mg} \mathrm{L}^{-1}\right)$. Total RBC $\left(10^{6}\right.$ per $\left.\mathrm{mm}^{3}\right)$ and WBC $\left(10^{3}\right.$ per $\left.\mathrm{mm}^{3}\right)$ were determined manually with the improved Neubauer counting chamber. Haemoglobin was determined according to the cyanmethemoglobin procedure (Blaxhall \& Rao, 1973) and expressed in $\mathrm{g} \mathrm{dL}^{-1}$. Lymphocyte $\left(10^{3} \mu \mathrm{L}^{-1}\right)$ was determined by using Auto Hematology Analyser Mindray BC2800, Mindray ${ }^{\circledR}$ Shenzhen, China. In order to measure serum protein in the blood, $0.1 \mathrm{~mL}$ of fish blood was withdrawn, mixed with 0.1 $\mathrm{mL}$ of EDTA and dissolved in $0.2 \mathrm{~mL}$ of $\mathrm{NaCL}$ $0.9 \%$. The mixture was centrifuged $1000 \mathrm{rpm}$ for
15 minutes. The supernatant was used for serum protein determination by using Biolis 24i, Tokyo Boeki Machinery Ltd. Japan.

\section{Statistical Analysis}

Results are expressed as means \pm standard error (SE) and data were analyzed using SPSS version 22 (SPSS, Inc., USA). The data of Survival was transformed to arcsine, water quality, $\mathrm{RBC}, \mathrm{WBC}$, total $\mathrm{Hb}$, the percentage of lymphocyte, and total protein serum on the day 30 of the trial were subjected to one-way ANOVA, followed by Duncan post hoc test to evaluate significant differences among the group of treatments. All significant tests were at $P<0.05$ levels.

\section{RESULTS AND DISCUSSION}

\section{Water Quality}

Fish have a close relationship with their surrounding aquatic environment. Most aquarium fish such as Betta sp lives in a closed system which is mean that water needs to be manually removed and added to be renewed. The TCL has traditionally been used by Betta sp breeders in South East Asia, including Indonesia to mimic the natural Betta sp habitat. The TCL contains many hydrolyzable tannins, namely terflavins A, terflavins B, tergallagin, tercatin, punicalin, punicalagin, chebulagic acid, geraniin, granatin $\mathrm{B}$, and corilagin (Tanaka et al., 1986; Chen \& Li, 2006).

Based on the present results, temperature and DO were not affected by any concentration of TCL immersion whereas immersion $625 \mathrm{ppm}$ of TCL showed significantly lowest $\mathrm{pH}(5.05 \pm$ 0.10 ) in the fish medium (Table 1). The decline in $\mathrm{pH}$ could be due to the tannin content in the TCL. According to Zhao et al. (1999), tannins have potential commercial applications in aquaculture. However, tannin may reduce water $\mathrm{pH}$ (Miksen \& Media, 2016).

\section{Phytochemical Content}

Numbers of plant extract which have active ingredients and various biological activities have been reported as supplementation in aquaculture field (Citarasu, 2010; Madhuri et al., 2013; Chakraborty et al., 2014; Sivasankar et al., 2015; Syahidah et al., 2015). However, data regarding the phytochemical of T. catappa and its effect on the fish, especially Betta $s p$ is scarce. Practically, the screening test of the phytochemical compound in T. catappa is important to be done to find out the benefit of plant bioactive agents in fish. The use of ethanol as an extractor is due to its capability to bind phytochemical compounds 
Table 1. Water quality of Betta sp-immersed medium with a various concentration of Terminalia catappa leaves extract.

\begin{tabular}{lllllll}
\hline Variables & Control & $125 \mathrm{ppm}$ & $250 \mathrm{ppm}$ & $375 \mathrm{ppm}$ & $500 \mathrm{ppm}$ & $625 \mathrm{ppm}$ \\
\hline Temperature & $25.57 \pm 0.030$ & $25.58 \pm 0.016$ & $25.57 \pm 0.054$ & $25.73 \pm 0.223$ & $25.62 \pm 0.014$ & $25.62 \pm 0.014$ \\
DO & $3.35 \pm 0.193$ & $3.48 \pm 0.073$ & $3.37 \pm 0.073$ & $3.05 \pm 0.220$ & $3.43 \pm 0.166$ & $3.43 \pm 0.166$ \\
$\mathrm{pH}$ & $6.14 \pm 0.008^{\mathrm{a}}$ & $6.125 \pm 0.014^{\mathrm{a}}$ & $6.175 \pm .014^{\mathrm{b}}$ & $6.21 \pm 0.464^{\mathrm{b}}$ & $6.25 \pm 0.166^{\mathrm{b}}$ & $5.05 \pm 0.100^{\mathrm{c}}$ \\
\hline
\end{tabular}

Data are given as mean values (Mean $\pm \mathrm{SE}$ ). Different superscript $(a, b, c)$ in the same row indicates significantly different mean values at $P<0.05$. Terminalia catappa leaves extract was added as an immersion. Temperature $=$ $\left({ }^{0} \mathrm{C}\right) ; \mathrm{DO}=\left(\mathrm{mg} \mathrm{mL}^{-1}\right)$

such as tannin, polyphenol, flavonoid, terpenoids, and saponin (Cowan, 1999; Ayini et al., 2014). The current study indicated the presence of saponin, triterpenoid, quinon, phenolic, tannins, and flavonoid in the TCL (Table 2).

Table 2. Phytochemical screening test of Terminalia catappa leaves extract

\begin{tabular}{lc}
\hline Phytochemicals & Results \\
\hline Alkaloid & - \\
Saponin & + \\
Steroid & - \\
Triterpenoid & + \\
Quinon & + \\
Phenolic & + \\
Tanin & + \\
Flavonoid & + \\
\hline
\end{tabular}

(+) Present; (-) Absent

Saponin is considered as anti-nutritional in field aquaculture. However, previous experiments stated that saponin had several beneficial effects on some fish such as common carp (Cyprinus carpio) and Nile tilapia (Oreochromis niloticus) (Stadlander, 2012). It is also revealed that low level of saponin was improved growth rate, feed conversion efficiency, protein utilization and reduced oxygen consumption. Also, saponin had various effects on the physiological status such us, increasing the number of RBC, hemoglobin, hematocrit, oxygen uptake and binding capacity in Perch (Anabas testudineus) (Roy \& Munshi, 1989).

Besides saponin, another group of phytochemicals, such astriterpenoid, quinon, phenolic are also a common plant active compound that can be found in TCL and has been reported to promote various activities like antistress, growth promotion, appetite stimulation, tonic, and immune booster (Citarasu, 2010; Chakraborty et al., 2012; Chakraborty et al., 2014). Meanwhile, tannins and flavonoid which were a presence in TCL are the main group of plant phenolic compound that act as primary an- tioxidants or free radical scavengers. According to Chansue and Assawawongkasem (2008), tannin from $T$. catappa extract with water has the ability as an antibacterial substance for ornamental fish. The tannin could inhibit the growth of bacteria in intestinal of fish by binding iron and form a chelate. On the one hand, flavonoid is one of the most widespread groups of phytochemicals in the plant that was shown to improve reproduction of Japanese Medaka (Oryzias latipes) (Kiparissis, 2001). It acts as antimicrobial properties on fish pathogen (Rattanachaikunsopon \& Phumkhachorn, 2007), and as a growth promoter on juvenile Pargus major (Ji et al., 2007), Carassius auratus (Ahilan. B et al., 2010), Catla catla (Kaleeswaran et al., 2011). Thus, the presence of secondary metabolites in TCL might play a role in the survival and blood profile of Betta sp.

\section{Survival Rate}

According to Chakraborty \& Hancz (2011), phytochemicals such as alkaloids, flavonoids, pigments, phenolics, and terpenoids are secondary metabolites in plants. The phytochemicals contained in the plant may enhance the innate immune system that may be of immense use in fish culture. Further, the phytochemical may improve the survival rate of the fish. Some previous studies have been conducted to evaluate the use of phytochemicals from various parts of plants extract to enhance the survival rate of the Common Carp (Cyprinus carpio); marine ornamental fish (Balachandran \& Tissera, 2013), and tilapia (Oreochromis niloticus) (Akinwande et al., 2011).

The present study indicated that Betta sp added with the immersion of TCL above 375 ppm showed significantly higher $(P<0.05)$ survival rate. The highest survival rate (Fig. 1) was found in Betta sp added $625 \mathrm{ppm}$ of TPC. This finding was in line with previous research that there was no significant evidence on the mortality of Betta sp after exposure of phytochemicals (Clotfelter \& Rodriguez, 2006). Furthermore, Ashraf and Bengtson (2007) revealed that the 


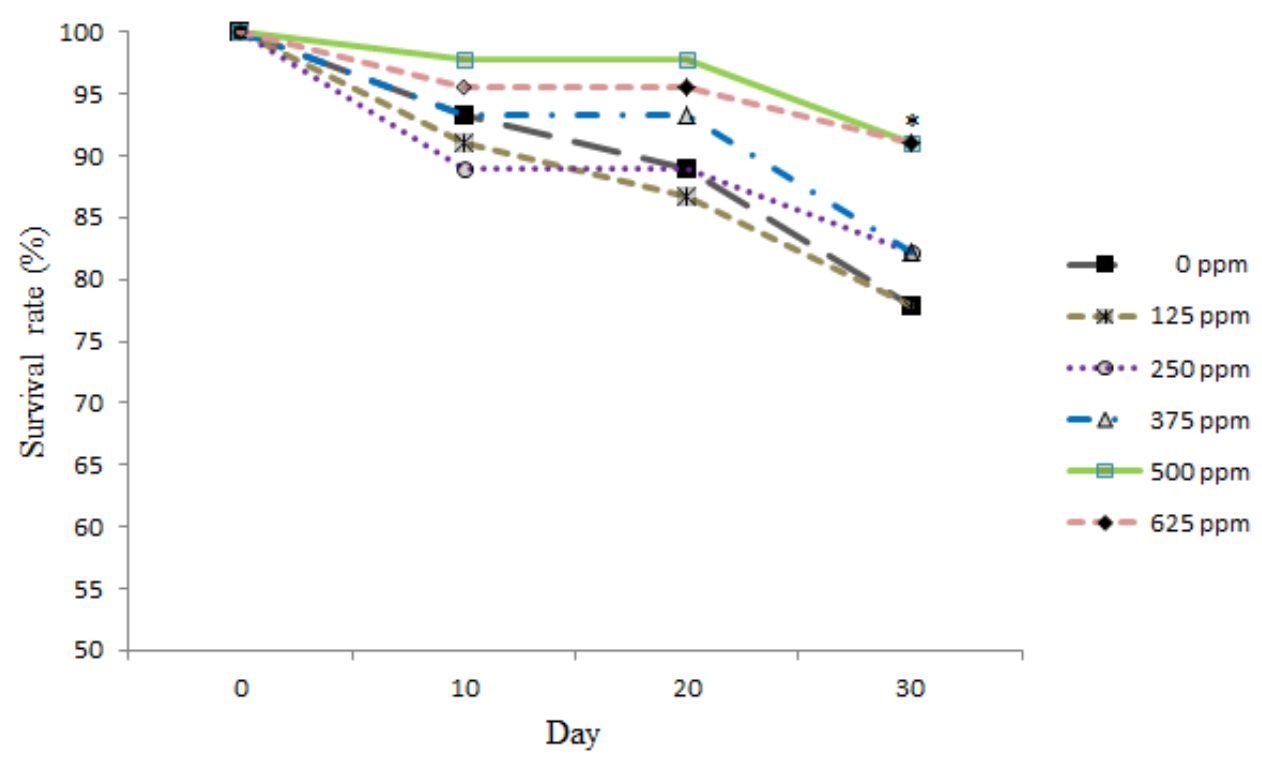

Figure 1. Survival rate (\%) of ornamental fish (Betta sp) after various immersion concentration (ppm) of Terminalia catappa extract for 30 days. $\left({ }^{*}\right)$ The highest survival rate ( $625 \mathrm{ppm}$ of TCL)

presence of tannin in feeding had positive effects on the survival of larval striped bass (Morone saxatilis). However, some previous studies stated that tannin which presents dominantly in plant had negative effects in Channa straitus and Cyprinus carpio (Viswaranjan et al., 1988), the use of tannin can absorb harmful chemicals, give soothing and suitable environment fairly benign for fish (VanSumere et al., 1975; Ashraf \& Bengtson, 2007).

The biological effects of saponin including survival and immune system, on fish, have also been widely studied and reviewed by several scientists. Saponins are found in plants, contain either a steroid or triterpenoid aglycone to which one or more sugar chains are attached (Oda et al., 2003). Furthermore, the use of 1 and $2 \mathrm{mg}$ $\mathrm{L}^{-1}$ saponin in white shrimp Litopenaeus vannamei increased the survival rate of shrimp (Su \& Chen, 2008). In contrast, it was observed that pure saponin at high levels caused severe stress and mortality, following exposure to $200 \mathrm{mg} \mathrm{L}^{-1}$ (Nagesh et al., 1999).

\section{Blood Profile}

Currently, application of phytochemical on the haematological indices is common in the culture of aquatic animals, including fish. Haematological parameters are gaining increasing importance in aquaculture because of its value in assessing the health status of fish (Schütt et al., 1997; Kori-Siakpere et al., 2005; Metin et al., 2008; Karimi et al., 2013; Suely et al., 2016). Haematological parameters such as RBC, WBC, $\mathrm{Hb}$, lymphocyte, and TPC are pivotal role in assessing the physiological condition of the fish. Based on the current results found that groups of fish treated with TCL above 375 had higher RBC, WBC, and $\mathrm{Hb}$ than any others group whereas the lowest lymphocyte resulted in fish treated with $125 \mathrm{ppm}$. However, TPC of fish was not affected by any treatments. The RBC, WBC, Hb, lymphocyte are used as an indicator of haematological status in fish in related to innate immune defence and regulation of immunological function in the organisms (Ballarin et al., 2004).

The underlying mechanism(s) whereby TCL boosts the haematological indices of Betta sp is not properly understood. However, Nair, et al. (2002); Lyu and Park (2005) stated that flavonoid from plant metabolite may contribute to promoting cellular immunity by modulating $\mathrm{Th}-1$ derived cytokines such as IL-2 (Interleukin 2) and INFy (Interferon). Flavonoid can be a bio catalysator to produce leukocytes and stimulate leukocytes as nonspecific cellular immunity. Also, flavonoid has a positive effect of reducing RBC hemolysis, by protecting biological membranes of RBC from free radical which induces oxidative damage (Kitagawa et al., 1992; Asgary et al., 2005). Also, some investigators reported that the antioxidants present in the plant extract might trigger erythropoiesis and antioxidant activity (Shadu et al., 2006; Vargeshe et al., 2010; Lestari $\&$ Susanti, 2015). It seems in agreement with the present study as the TCL has flavonoids that capable as an antioxidant which may maintain the heme iron in its ferrous state and this could enhance erythropoiesis (Akah et al., 2008; Uboh et 
Rudy Agung Nugroho et al. / Biosaintifika 8 (2) (2016) 240-247

Table 3. Blood profile of Betta sp added various concentrations (ppm) of Terminalia catappa leaves extract for 30 days

\begin{tabular}{|c|c|c|c|c|c|c|}
\hline Parameter & \multicolumn{5}{|c|}{ Groups (ppm) } & 625 \\
\hline $\operatorname{RBC}\left(10^{6} \mu \mathrm{L}^{-1}\right)$ & $1.846 \pm 0.007^{\mathrm{a}}$ & $1.842 \pm 0.007^{\mathrm{a}}$ & $1.846 \pm 0.019^{\mathrm{a}}$ & $1.853 \pm 0.027^{\mathrm{a}}$ & $2.014 \pm 0.050^{\mathrm{b}}$ & $2.014 \pm 0.033^{b}$ \\
\hline WBC $\left(10^{3} \mu \mathrm{L}^{-1}\right)$ & $4.345 \pm 0.073^{\mathrm{a}}$ & $4.376 \pm 0.071^{\mathrm{ab}}$ & $4.606 \pm 0.265^{\mathrm{ab}}$ & $5.006 \pm 0.313^{\mathrm{abc}}$ & $5.138 \pm 0.306^{\mathrm{bc}}$ & $5.430 \pm 0.227^{c}$ \\
\hline $\begin{array}{l}\text { Haemoglobin } \\
\left(\mathrm{g} \mathrm{dL}^{-1}\right)\end{array}$ & $7.400 \pm 0.048^{a}$ & $7.520 \pm 0.015^{\mathrm{ab}}$ & $7.749 \pm 0.197^{\mathrm{ab}}$ & $7.748 \pm 0.070^{\mathrm{ab}}$ & $8.414 \pm 0.076^{\mathrm{c}}$ & $8.581 \pm 0.117^{\mathrm{c}}$ \\
\hline $\begin{array}{l}\text { Total protein } \\
\text { serum (mg } \\
\left.\mathrm{dL}^{-1}\right)\end{array}$ & $0.492 \pm 0.006^{\mathrm{a}}$ & $0.518 \pm 0.005^{a}$ & $0.492 \pm 0.010^{\mathrm{a}}$ & $0.509 \pm 0.003^{a}$ & $0.500 \pm 0.007^{a}$ & $0.506 \pm 0.005^{a}$ \\
\hline
\end{tabular}

al., 2010; Shatoor, 2011).

Though saponin that is naturally occurring surface-active glycosides has been reported to have a toxic effects at high level on fish (Francis et al., 2002), Roy and Munshi (1989) revealed that there was an increasing in the erythrocyte, haemoglobin and packed cell of Anabas testudineus after exposure to $5 \mathrm{mg}$ of saponin per liter in the water for $24 \mathrm{~h}$. Nevertheless, the mechanisms of the immune-stimulating action of saponin in TCL are not clearly understood. Previous research predicted that saponin might induce the production of cytokines such as interleukin and interferon that could mediate their immunostimulant effects (Rajput et al., 2007; Helal \& Melzig, 2011). Also, saponin enhances not only macrophage but also T-cell activities in finfish (Xiong et al., 2012).

\section{CONCLUSION}

Immersion above 375 ppm of TCL, containing some beneficial phytochemicals such as tannin, flavonoid, and saponin in the Betta sp is recommended to enhance survival and blood profile. The water quality, especially temperature and DO was not affected by immersion of TCL. However, giving high TCL concentration (625 ppm) in the fish medium reduced $\mathrm{pH}$. Further research needs to be conducted to validate the effects of TCL immersion on the antioxidant enzymes activity, such as glutathione peroxide, superoxide dismutase, and catalase as well as levels of lipid peroxidase that are related to the health and immunity of Betta sp.

\section{ACKNOWLEDGEMENT}

The authors are grateful to Research, Technology, and General Higher Education Mi- nistry, Government of Indonesia for the financial support No 189/UN17.16/PG/2015. (DIPA023.04.1.673453/2015). Authors' gratitude is also extended to the following: Mulawarman University, especially Department Biology, Faculty of Mathematics and Natural Sciences for all supports.

\section{REFERENCES}

Ahilan. B, Nithiyapriyatharshini, A., \& Ravaneshwaran, K. (2010). Influence of certain herbal additives on the growth, survival and disease resistance of goldfish, Carassius auratus (Linneaus) Tamilnadu. Journal of Veterinary and Animal Sciences, 6(1), 5-11.

Akah, P., Okpi, O., \& Okoli, C. (2008). Evaluation of the anti-inflammatory, analgesic and antimicrobial activities of bark of Afzelia africana. Nigerian Journal of Natural Products and Medicine, 11(1), 48-52.

Akinwande, A., Dada, A., \& Moody, F. (2011). Effect of dietary administration of the phytochemical "Genistein"(3, 5, 7, 3, 4 Pentahydroxyflavone) on masculine tilapia, Oreochromis niloticus.

Asgary, S., Naderi, G. H., \& Askari, N. M. S. (2005). Protective effect of flavonoids against red blood cell hemolysis by free radicals. Experimental Cardiology, 10(2), 88-90.

Ashraf, M., \& Bengtson, D. A. (2007). Effect of tannic acid on feed intake, survival and growth of striped bass (Morone saxatilis) larvae. International Journal of Agriculture and Biology, 9, 751-754.

Ayini, U., B., S. H., \& Dewi, T. C. (2014). Efek antibakteri ekstrak daun mimba (Azadirachta indica A. Juss) terhadap bakteri Vibrio algynoliticus secara In vitro. Biosaintifika: Journal of Biology \& Biology Education, 6(1), 67-75.

Balachandran, N., \& Tissera, K. (2013). A study on the effect of using mangrove leaf extracts as a feed additive in the progress of bacterial infections in marine ornamental fish. Journal of Coastal Life Medicine, 1(3), 217-224. 
Ballarin, L., Dall'Oro, M., Bertotto, D., Libertini, A., Francescon, A., \& Barbaro, A. (2004). Haematological parameters in Umbrina cirrosa (Teleostei, Sciaenidae): a comparison between diploid and triploid specimens. Comparative Biochemical Physiology Part A: Molecular and Integrative Physiology, 138(1), 45-51.

Blaxhall, B. R., \& Rao, K. S. (1973). Routine haematological methods for use with fish blood. Journal of Fish Biology, 5(6), 771-781.

Chakraborty, S. B., \& Hancz, C. (2011). Application of phytochemicals as immunostimulant, antipathogenic and antistress agents in finfish culture. Reviews in Aquaculture, 3(3), 103-119.

Chakraborty, S. B., Horn, P., \& Hancz, C. (2014). Application of phytochemicals as growth-promoters and endocrine modulators in fish culture. $R e$ views in Aquaculture, 6(1), 1-19.

Chakraborty, S. B., Molnár, T., \& Hancz, C. (2012). Effects of methyltestosterone, tamoxifen, genistein and Basella alba extract on masculinization of guppy (Poecilia reticulata). Journal of Applied Pharmaceutical Science, 2(12), 48-52.

Chandel, A. K., Lakshmi Narasu, M., Chandrasekhar, G., Manikyam, A., \& Venkateswar Rao, L. (2009). Use of Saccharum spontaneum (wild sugarcane) as biomaterial for cell immobilization and modulated ethanol production by thermotolerant Saccharomyces cerevisiae VS3. Bioresource Technology, 100(8), 2404-2410.

Chansue, N., \& Assawawongkasem, N. (2008). The in vitro antibacterial activity and ornamental fish toxicity of the water extract of Indian Almond leaves (Terminalia catappa Linn.). KKU Veterinary Journal, 18(1), 36-45.

Chen, P. S., \& Li, J. H. (2006). Chemopreventive effect of punicalagin, a novel tannin component isolated from Terminalia catappa, on H-ras-transformed NIH3T3 cells. Toxicology letters, 163(1) 44-53.

Chitmanat, C., Tongdonmuan, K., Khanom, P., Pachontis, P., \& Nunsong, W. (2003). Antiparasitic, antibacterial, and antifungal activities derived from a Terminalia catappa solution against some tilapia (Oreochromis niloticus) pathogens. In: III WOCMAP Congress on Medicinal and Aromatic Plants-Volume 4: Targeted Screening of Medicinal and Aromatic Plants, Economics 678. pp. 179-182.

Citarasu, T. (2010). Herbal biomedicines: a new opportunity for aquaculture industry. Aquaculture International, 18(3), 403-414.

Clotfelter, E. D., \& Rodriguez, A. C. (2006). Behavioral changes in fish exposed to phytoestrogens. Environmental Pollution, 144(3), 833-839.

Cowan, M. M. (1999). Plant products as antimicrobial agents. Clinical microbiology reviews, 12(4), 564582.

Ekman, A., Wallberg, O., Joelsson, E., \& Börjesson, P. (2013). Possibilities for sustainable biorefineries based on agricultural residues - A case study of potential straw-based ethanol production in Sweden. Applied Energy, 102, 299-308.

Francis, G., Kerem, Z., Makkar, H. P., \& Becker, K.
(2002). The biological action of saponins in animal systems: a review. British Journal of Nutrition, 88(6), 587-605.

Helal, R., \& Melzig, M. F. (2011). In vitro effects of selected saponins on the production and release of lysozyme activity of human monocytic and epithelial cell lines. Scientia Pharmaceutica, 79(2), 337-349.

Hyttel, P., Sinowatz, F., \& Vejlsted, M. (2010). Essentials of domestic animal embryology. UK: Elsevier Health Sciences.

Hyttel, P., Sinowatz, F., Vejlsted, M., \& Betteridge, K. (2009). Essentials of domestic animal embryology. UK: Elsevier Health Sciences.

Inama, L., Diré, S., Carturan, G., \& Cavazza, A. (1993). Entrapment of viable microorganisms by $\mathrm{SiO} 2$ sol-gel layers on glass surfaces: Trapping, catalytic performance and immobilization durability of Saccharomyces cerevisiae. Journal of Biotechnology, 30(2), 197-210.

Ji, S. C., Takaoka, O., Jeong, G.-S., Lee, S.-W., Ishimaru, K., Seoka, M., \& Takii, K. (2007). Dietary medicinal herbs improve growth and some nonspecific immunity of red sea bream Pagrus major. Fisheries Science, 73(1), 63-69.

Kaleeswaran, B., Ilavenil, S., \& Ravikumar, S. (2011). Growth response, feed conversion ratio and antiprotease activity of Cynodon dactylon (L.) mixed diet in Catla catla (Ham.). Journal of Animal and Veterinary Advances, 10(4), 511-517.

Karimi, S. H., Kochinian, P., \& Salati, A. P. (2013). Short Paper: The effect of sexuality on some haematological parameters of the yellowfin seabream, Acanthopagrus latus in Persian Gulf. Iranian Journal of Veterinary Research, 14(1), 6568.

Kiparissis, Y. (2001). Effects of flavonoids and other phytochemicals on fish Cypia monooxygenases, embryonic and reproductive development, Trent University, Canada.

Kitagawa, S., Fujisawa, H., \& Sakurai, H. (1992). Scavenging effects of dihydric and polyhydric phenols on superoxide anion radicals, studied by electron spin resonance spectrometry. Chemical and Pharmaceutical Bulletin, 40(2), 304-307.

Kori-Siakpere, O., Ake, J. E. G., \& Idoge, E. (2005). Haematological characteristics of the African snakehead, Parachanna obscura. African Journal of Biotechnology, 4(6), 527-530.

Lestari, R. D., \& Susanti, R. (2015). Effectivity of Pedada Fruit (Sonneratia caseolaris) Extract to The Level of Sgot and Sgpt in Rat Treated by Paracetamol Induction. Biosaintifika: Journal of Biology \& Biology Education, 7(1), 29-36.

Lyu, S. Y., \& Park, W. B. (2005). Production of cytokine and NO by RAW 264.7 macrophages and PBMC in vitro incubation with flavonoids. $A r$ chives of Pharmacal Research, 28(5), 573-581.

Madhuri, S., Mandloi, A. K., Govind, P., \& Sahni, Y. P. (2013). Antimicrobial activity of some medicinal plants againts fish pathogen. International Research Journal of Pharmacy, 3, 28-30.

Meena, K., \& Raja, T. K. (2006). Immobilization of Saccharomyces cerevisiae cells by gel entrapment using 
various metal alginates. World Journal of Microbiology and Biotechnolog, 22(6), 651-653.

Metin, K., Koca, Y. B., Kiral, F. K., Koca, S., \& Türkozan, O. (2008). Blood cell morphology and plasma biochemistry of captive Mauremys caspica (Gmelin, 1774) and Mauremys rivulata (Valenciennes, 1833). Acta Veterinaria Brno, 77(2), 163-174.

Miksen, C., \& Media, D. (2016). Aquariums: How does tannic acid affect aquariums? http://pets.thenest.com/tannic-acid-affect-aquariums-12501. html Accessed 02 June 20162016.

Nagesh, T. S., Jayabalan, N., Mohan, C. V., Annappaswamy, T. S., \& Anil, T. M. (1999). Survival and histological alterations in juvenile tiger shrimps exposed to saponin. Aquaculture International, 7(3), 159-167.

Nair, M. P. N., Kandaswami, C., Mahajan, S., Chadha, K. C., Chawda, R., Nair, H., Kumar, N., Nair, R. E., \& Schwartz, S. A. (2002). The flavonoid, quercetin, differentially regulates Th-1 (IFN $\gamma$ ) and Th-2 (IL4) cytokine gene expression by normal peripheral blood mononuclear cells. Biochimica et Biophysica Acta (BBA) - Molecular Cell Research, 1593(1), 29-36.

Oda, K., Matsuda, H., Murakami, T., Katayama, S., Ohgitani, T., \& Yoshikawa, M. (2003). Relationship between adjuvant activity and amphipathic structure of soyasaponins. Vaccine, 21(17), 21452151.

Pandey, G. (2013). Some Medicinal Plants to Treat Fish Ectoparasitic Infections. International Journal of Pharmaceutical and Research Sciences, 2(2), 532538.

Rajput, Z. Q., Hu, S. H., Xiao, C. W., \& Arijo, A. G. (2007). Adjuvant effects of saponins on animal immune responses. Journal of Zhejiang University. Science. B, 8(3), 153-161.

Rattanachaikunsopon, P., \& Phumkhachorn, P. (2007). Bacteriostatic effect of flavonoids isolated from leaves of Psidium guajava on fish pathogens. Fitoterapia, 78(6), 434-436.

Roy, P. K., \& Munshi, J. P. (1989). Effect of saponin extracts on oxygen uptake and hematology of an-breathing climbing perch, Anabas testudineus (Bloch). Journal of Freshwater Biologi, 1(2), 167172.

Schütt, D. A., Lehmann, J., Goerlich, R., \& Hamers, R. (1997). Haematology of swordtail, Xiphophorus helleri. I: blood parameters and light microscopy of blood cells. Journal of Applied Ichthyology, 13(2), 83-89

Shadu, S. K., Firoj, A., Takashi, O., \& Masami, I. (2006). Flavonoids from Sonneratia caseolaris. Journal of Natural Medicines, 60(3), 264-265.

Shatoor, A. S. (2011). Acute and sub-acute toxicity of Crataegus aronia syn. azarolus (L.) whole plant aqueous extract in wistar rats. American Journal of Pharmacology and Toxicology, 6(2), 37-45.

Sivasankar, P., Anix Vivek Santhiya, A., \& Kanaga, V. (2015). A review on plants and herbal extracts against viral diseases in aquaculture. Journal of Medicinal Plants Studies, 3(2), 75-79.

Stadlander, T. (2012). Saponin fractions from fenugreek
(Trigonella foenum-graecum L.) as dietary supplements for Nile tilapia (Oreochromis niloticus L.) and common carp (Cyprinus carpio L.), Universität Hohenheim, Bremen.

Su, B. K., \& Chen, J. C. (2008). Effect of saponin immersion on enhancement of the immune response of white shrimp Litopenaeus vannamei and its resistance against Vibrio alginolyticus. Fish \& Shellfish Immunology, 24(1), 74-81.

Suely, A., Zabed, H., Ahmed, A. B. A., Mohamad, J., Nasiruddin, M., Sahu, J. N., \& Ganesan, P. (2016). Toxicological and hematological effect of Terminalia arjuna bark extract on a freshwater catfish, Heteropneustes fossilis. Fish physiology and biochemistry, 42(2), 431-444.

Syahidah, A., Saad, C. R., Daud, H. M., \& Abdelhadi, Y. M. (2015). Status and potential of herbal applications in aquaculture: A review. Iranian Journal of Fisheries Sciences, 14(1), 27-44.

Tanaka, T., Nonaka, G.-I., \& Nishioka, I. (1986). Tannins and related compounds. XLII. : Isolation and characterization of four new hydrolyzable tannins, terflavins $\mathrm{A}$ and $\mathrm{B}$, tergallagin and tercatain from the leaves of Terminalia catappa $\mathrm{L}$. Chemical \& Pharmaceutical Bulletin, 34(3), 10391049.

Uboh, F. E., Okon, I. E., \& Ekong, M. B. (2010). Effect of aqueous extract of Psidium guajava leaves on liver enzymes, histological integrity and hematological indices in rats. Gastroenterology Research, 3(1), 32-38.

Van-Sumere, C. F., Albrecht, J., Dedonder, A., Depooter, H., \& Pe, I. (1975). Plant proteins and phenolics. In: Annual Proceedings of phytochemistry Society,. pp. 211-264.

Vargeshe, J. K., Belzik, N., Nisha, A. R., Resmi, S., \& Silvipriya, K. S. (2010). Pharmacognostical and phytochemical studies of a mangrove (Sonneratia caseolaris) from Kochi of Kerala State in India. Journal of Pharmacy research, 3(11), 2625-2627.

Viswaranjan, S., Beena, S., \& Palavesam, A. (1988). Effect of tannic acid on the protein, carbohydrate and lipid levels in the tissues of the fish Oreochromis mossambicus. Environmental Ecology, 6(2), 289-292.

Vučurović, V. M., \& Razmovski, R. N. (2012). Sugar beet pulp as support for Saccharomyces cerivisiae immobilization in bioethanol production. Industrial Crops and Products, 39, 128-134.

Xiong, S. L., Hou, D. B., Huang, N., \& Li, A. (2012). Preparation and biological activity of saponin from Ophiopogon japonicus. African Journal of Pharmacy and Pharmacology, 6(26), 1964-1970.

Zhao, G., Jaiteh, A. A., Wang, W., \& Stevens Jr, S. E. (1999). Effects of selected water quality variables on the persistence of tannic acid and related compounds under simulated aquaculture conditions. North American journal of aquaculture, 61(4), 304-309.

Zhou, Z. D., Li, G. Y., \& Li, Y. J. (2010). Immobilization of Saccharomyces cerevisiae alcohol dehydrogenase on hybrid alginate-chitosan beads. International Journal of Biological Macromolecules, 47(1), 21-26. 